\title{
Pengaruh Penambahan Bubuk Jahe Emprit (Zingiber officinale var. Amarum) Terhadap Karakteristik Teh Celup Herbal Daun Ciplukan (Physalis angulata L.)
}

\section{Effect Of Addition Of Emprit Ginger Powder (Zingiber Officinale var. Amarum) On Characteristic Of Tea Herbal Of Ciplukan Leaf (Physalis Angulata L.)}

\author{
I Gede Widiyana ${ }^{1}$, Ni Made Yusa ${ }^{1 *}$, I Made Sugitha ${ }^{1}$ \\ Program Studi Ilmu dan Teknologi Pangan, Fakultas Teknologi Pertanian, Universitas Udayana \\ Kampus Bukit Jimbaran, Badung-Bali \\ *Penulis korespondensi: Ni Made Yusa, Email: madeyuse@unud.ac.id
}

\begin{abstract}
This study aims to determine the effect of the addition of emprit ginger powder and the right addition to getting the best ciplukan leaf herbal characteristics. The design used in this study was a Completely Randomized Design with the treatment of the addition of emprit ginger powder consisting of 5 levels, namely $0 \%, 10 \%, 20 \%, 30 \%$, and $40 \%$. This study was repeated three times to obtain 15 experimental units. The data obtained were analyzed by analysis of variance and if the treatment had a significant effect it was followed by Duncan's Multiple Range (DMRT) test. The results showed that ciplukan leaf herbal tea with the addition of $20 \%$ emprit ginger powder was the best treatment with the criteria of water content value of $7.84 \%$, total phenol $1.18 \mathrm{mgGAE} / \mathrm{g}$, total flavonoid $0.56 \mathrm{mgQE} / \mathrm{g}$, antioxidant activity $58.02 \%$, $\mathrm{IC}_{50} 812.96$ ppm, yellowish-brown color, somewhat distinctive flavor of ciplukan tea leaves and somewhat dislike, rather bitter taste, and overall rather dislike reception.
\end{abstract}

Keywords: Ciplukan tea, ginger emprit, tea bags

\section{PENDAHULUAN}

Teh herbal merupakan produk minuman teh dalam bentuk tunggal atau campuran herbal lainnya yang memiliki khasiat beragam dalam membantu pengobatan suatu penyakit tergantung jenis bahan herbal yang digunakan (Daroini, 2006). Teh herbal dapat dibuat dari bahan dedaunan, biji-bijian, bunga, dan akar dari tanaman. Salah satu tanaman herbal yang dapat dibuat menjadi teh adalah daun Physalis angulata $\mathrm{L}$ atau dikenal sebagai ciplukan.

Daun ciplukan mengandung flavonoid $683,77 \mathrm{mg} / 100 \mathrm{~g}$, alkaloid 1,85 $\mathrm{mg} / 100 \mathrm{~g}$, dan withanolides bebas 17,72 $\mathrm{mg} / 100 \mathrm{~g}$ yang bermanfaat baik bagi kesehatan (Phuah dkk., 2016). Hal ini dibuktikan dari berbagai penelitian yang menjelaskan bahwa daun ciplukan berkhasiat menurunkan kadar gula darah, mengobati penyakit bisul, influenza, kanker payudara MCF-7 dan brongkitis (Suprianto, 2013; Nuranda dkk., 2016; Fitria dkk., 2011). Masalah yang dihadapi dalam pembuatan teh daun ciplukan adalah memiliki karakteristik rasa pahit dan aroma off-flavour dari daun ciplukan yang tidak disukai oleh sebagian orang. Rasa pahit pada daun ciplukan berasal dari senyawa saponin dan alkaloid yang sekaligus memberikan manfaat berupa antitumor dan menghambat 
pertumbuhan kanker usus besar (Taryati, 2010). Selain itu adanya kandungan flavonoid dan tanin dalam tanaman ciplukan juga berkontribusi dalam memberikan rasa pahit. Untuk menutupi rasa pahit dan aroma off-flavour tersebut perlu ditambahkan jahe emprit sehingga dapat meningkatkan daya terima masyarakat.

Jahe emprit merupakan salah satu tanaman rempah yang dapat digunakan sebagai bahan penyedap serta memperbaiki off-flavour dari makanan dan minuman. Berbagai penelitian menjelaskan bahwa jahe emprit mampu menutupi rasa pahit dan aroma off-flavour dari teh daun afrika dan teh daun sirsak dengan perlakuan penambahan jahe emprit sebesar $40 \%$ (Muzaki dan Wahyuni, 2015; Sulistiani., dkk 2019). Hal ini dikarena jahe emprit memiliki rasa pedas yang disebabkan oleh adanya kandungan ginggerol dan shogaol yang sekaligus berperan sebagai antioksidan. Selain itu jahe emprit menghasilkan aroma harum yang disebabkan oleh adanya minyak volatil yang terdiri dari zingiberen dan zingiberol. Jahe emprit memiliki keunggulan yaitu memiliki jumlah kandungan gingerol dan shogaol tertinggi diantara ketiga jenis jahe, yaitu $22,57 \mathrm{mg} / \mathrm{g} ; 2,24 \mathrm{mg} / \mathrm{g}$, jahe merah 18,03 $\mathrm{mg} / \mathrm{g} ; 1,36 \mathrm{mg} / \mathrm{g}$, dan jahe gajah 9,56 mg/g ; 0,92 mg/g (Fathona, 2011), sehingga dengan penambahan jahe emprit diharapkan mampu menutupi rasa pahit dan aroma offflavour dari teh daun ciplukan.
Penambahan jahe emprit diharapkan tidak hanya memperbaiki rasa dan aroma, tetapi dapat meningkatkan senyawa bioaktif teh daun ciplukan berupa total fenol, total flavonoid, dan aktivitas antioksidan. Produk teh dalam bentuk kemasan dapat lebih praktis dikonsumsi oleh masyarakat sehingga dibuat produk teh celup. Penelitian ini bertujuan untuk mengetahui pengaruh penambahan bubuk jahe emprit serta penambahan yang tepat untuk mendapatkan karakteristik teh celup herbal daun ciplukan terbaik.

\section{METODE PENELITIAN}

\section{Tempat dan Waktu}

Penelitian ini dilaksanakan di Laboratorium Pengolahan Pangan, Laboratorium Analisis Pangan, Laboratorium Rekayasa Proses dan Pengendalian Mutu, Fakultas Teknologi Pertanian Universitas Udayana. Penelitian ini dilakukan pada bulan Desember 2019 Maret 2020.

\section{Bahan dan Alat}

Bahan yang digunakan dalam penelitian ini adalah daun ciplukan yang diperoleh dari areal persawahan sepanjang Jalan Pesagi, Kecamatan Karangasem, Kabupaten Karangasem, Bali dan jahe emprit yang diperoleh dari Pasar Badung, Jalan Sulawesi, Kecamatan Denpasar Barat, Kota Denpasar, Bali. Bahan kimia yang digunakan yaitu 2,2-difenil-1-pikrilhidrazil (DPPH) (Himedia), Folin-Ciocalteu (Merck), metanol 
pro analisis (PA), standar asam galat (Merck), $\mathrm{Na}_{2} \mathrm{CO}_{3}$ (Merck), $\mathrm{AlCl}_{3}$ (Merck), standar kuersetin (sigma), aquades dan air es.

Alat-alat yang digunakan pada penelitian ini yaitu oven (ESCO Isotherm), blender (Vienta), ayakan 40 mesh (Retsch), timbangan analitik (Shimadzu ATY224), kantong teh berbahan kertas kraft, sealer (PFS-200), sentrifus (Danamon IEC), spektrofotometer (Genesys 10S UV-Vis), vortex (Maxi Mix II Type 367000), desikator, mikro pipet (Socorex), termometer, pisau, corong kaca (Pyrex), spatula, alumunium foil (Klin Pack), gelas ukur (Pyrex), erlenmeyer (Pyrex), botol gelap, gelas beaker, kufet kaca, pipet volume (Pyrex), pipet tetes, tabung reaksi (Pyrex), cawan aluminium, tabung sentrifus, labu ukur $5 \mathrm{ml}$ (Pyrex), labu ukur $100 \mathrm{ml}$ (Pyrex), dan gelas platik.

\section{Rancangan Penelitian}

Rancangan yang digunakan pada penelitian ini adalah Rancangan Acak Lengkap (RAL) dengan perlakuan penambahan bubuk jahe emprit terdiri dari 5 taraf yaitu; $0 \%, 10 \%, 20 \%, 30 \%$, dan $40 \%$ dan diulang sebanyak 3 kali sehingga diperoleh 15 unit percobaan. Data yang diperoleh dianalisis dengan sidik ragam dan apabila perlakuan berpengaruh terhadap parameter yang diamati maka dilanjutkan dengan uji Duncan's Multiple Range (DMRT) (Steel dan Torrie, 1993).

\section{Parameter yang diamati}

Parameter yang diamati dalam penelitian ini meliputi kadar air menggunakan metode oven (Sudarmadji dkk., 1997), total fenol menggunakan metode folin-ciocalteu (Sakanaka dkk., 2003), total flavonoid menggunakan metode spektrofotometri (Rahman dkk., 2006), aktivitas antioksidan dan $\mathrm{IC}_{50}$ menggunakan metode DPPH (Blois, 1958 dalam Hanani dkk., 2005), dan karakteristik sensori menggunakan uji rangking dan uji hedonik (Irmayanti, 2017).

\section{Pelaksanaan Penelitian}

Pelaksanaan penelitian meliputi beberapa tahap yaitu: Pembuatan bubuk daun ciplukan, pembuatan bubuk jahe emprit, dan pembuatan teh celup herbal daun ciplukan dengan jahe emprit.

\section{Pembuatan Bubuk Daun Ciplukan}

Pembuatan bubuk daun ciplukan diawali dengan proses pemetikan mulai dari daun termuda hingga empat helai daun dibawahnya dan disortasi bagian yang bagus. Proses selanjutnya pencucian daun untuk menghilangkan kotoran yang menempel menggunakan air mengalir dan ditiriskan. Selanjutnya dilakukan proses pengeringan menggunakan oven dengan suhu $50{ }^{\circ} \mathrm{C}$ selama 5 jam agar kadar air daun ciplukan dapat berkurang. Setelah kering dilakukan proses penghancuran menggunakan blender. Setelah hancur selanjutnya dilakukan pengayakan menggunakan ayakan 40 mesh. 


\section{Pembuatan Bubuk Jahe Emprit}

Pembuatan bubuk jahe emprit diawali dengan proses sortasi untuk memilih jahe emprit dengan kondisi baik dan dicuci dengan air mengalir untuk menghilangkan kotoran yang menempel. Dilakukan pengupasan dan diiris tipis dengan ketebalan $\pm 3 \mathrm{~mm}$. Selanjutnya di blansing menggunakan metode steam blansing dengan suhu $80^{\circ} \mathrm{C}$ selama 3 menit. Kemudian dilakukan pengeringan menggunakan oven pada suhu $60^{\circ} \mathrm{C}$ selama 6 jam. Setelah kering selanjutnya dihancurkan menggunakan blender kemudian diayak dengan ayakan 40 mesh.

\section{Pembuatan Teh Celup Herbal Daun Ciplukan Dengan Jahe Emprit}

Pembuatan teh celup herbal diawali dengan menimbang bubuk daun ciplukan dan bubuk jahe emprit sesuai perlakukan, kemudian dilakukan pengemasan menggunakan kantong teh berbahan kertas kraft berukuran 5,2 $\times 5,8 \mathrm{~cm}$ dengan berat masing - masing kantong teh 2 gram.

\section{HASIL DAN PEMBAHASAN}

Pada penelitian ini dilakukan pengujian terhadap bahan baku bubuk jahe emprit yang digunakan dengan hasil sebagai berikut; kadar air 7,04\%, total fenol 0,54 $\mathrm{mgGAE} / \mathrm{g}$, total flavonoid $0,14 \mathrm{mgQE} / \mathrm{g}$, dan aktivitas antioksidan 21,76\%. Nilai tersebut lebih kecil dibandingkan dengan hasil penelitian lainnya yang memperoleh nilai kadar air $7-12 \%$, total fenol 0,62 $\mathrm{mgGAE} / \mathrm{g}$, total flavonoid $0,80 \mathrm{mgQE} / \mathrm{g}$, dan aktivitas antioksidan 58,84\% (Eze, 2011; Susanti dan Binar, 2015; Pebiningrum dan Joni, 2018). Hal ini dipengaruhi oleh berbagai faktor seperti waktu panen, lingkungan tumbuh, dan letak geografis jahe emprit (Rosidi., dkk 2014). Hasil analisis kadar air, total fenol, total flavonoid, aktivitas antioksidan dan $\mathrm{IC}_{50}$ dari teh celup herbal daun ciplukan dapat dilihat pada Tabel 1.

Tabel 1. Nilai rata-rata kadar air, total fenol, total flavonoid, aktivitas antioksidan dan IC $_{50}$ dari teh celup herbal daun ciplukan.

\begin{tabular}{cccccc}
\hline $\begin{array}{c}\text { Perlakuan } \\
\text { penambahan } \\
\text { bubuk jahe }(\%)\end{array}$ & $\begin{array}{c}\text { Kadar Air } \\
(\% \mathrm{bb})\end{array}$ & $\begin{array}{c}\text { Total Fenol } \\
(\mathrm{mgGAE} / \mathrm{g})\end{array}$ & $\begin{array}{c}\text { Total } \\
\text { Flavonoid } \\
(\mathrm{mgQE} / \mathrm{g})\end{array}$ & $\begin{array}{c}\text { Aktivitas } \\
\text { Antioksidan } \\
(\%)\end{array}$ & $\begin{array}{c}\mathrm{IC}_{50} \\
(\mathrm{ppm})\end{array}$ \\
\hline P0 $(0 \%)$ & $7,11 \pm 0,12^{\mathrm{d}}$ & $1,03 \pm 0,03^{\mathrm{e}}$ & $0,49 \pm 0,01^{\mathrm{d}}$ & $31,23 \pm 0,24^{\mathrm{e}}$ & $1593,68 \pm 81,04^{\mathrm{a}}$ \\
P1 $(10 \%)$ & $7,21 \pm 0,09^{\mathrm{d}}$ & $1,11 \pm 0,02^{\mathrm{d}}$ & $0,53 \pm 0,01^{\mathrm{c}}$ & $47,20 \pm 0,79^{\mathrm{d}}$ & $1090,86 \pm 28,68^{\mathrm{b}}$ \\
P2 $(20 \%)$ & $7,84 \pm 0,05^{\mathrm{c}}$ & $1,18 \pm 0,01^{\mathrm{c}}$ & $0,56 \pm 0,01^{\mathrm{bc}}$ & $58,02 \pm 0,33^{\mathrm{c}}$ & $812,96 \pm 53,20^{\mathrm{c}}$ \\
P3 (30\%) & $8,26 \pm 0,21^{\mathrm{b}}$ & $1,25 \pm 0,01^{\mathrm{b}}$ & $0,58 \pm 0,02^{\mathrm{b}}$ & $62,23 \pm 0,34^{\mathrm{b}}$ & $768,60 \pm 12,08^{\mathrm{c}}$ \\
P4 (40\%) & $8,80 \pm 0,29^{\mathrm{a}}$ & $1,34 \pm 0,03^{\mathrm{a}}$ & $0,63 \pm 0,02^{\mathrm{a}}$ & $70,11 \pm 0,50^{\mathrm{a}}$ & $652,95 \pm 15,98^{\mathrm{d}}$ \\
\hline
\end{tabular}

Keterangan: Nilai rata-rata yang diikuti oleh huruf yang berbeda pada kolom yang sama menunjukkan perlakuan yang berbeda sangat nyata $(\mathrm{P}<0,01)$. 


\section{Kadar Air}

Hasil sidik ragam menunjukkan bahwa perlakuan penambahan bubuk jahe berpengaruh sangat nyata $(\mathrm{P}<0,01)$ terhadap kadar air teh celup herbal daun ciplukan. Berdasarkan Tabel 1 dapat dilihat bahwa kadar air tertinggi terdapat pada perlakuan P4 (40\% bubuk jahe) sebesar $8,80 \%$, sedangkan kadar air terendah terdapat pada perlakuan P0 (0\% bubuk jahe) sebesar $7,11 \%$.

Tabel 1 menunjukkan kadar air semakin meningkat seiring dengan meningkatnya penambahan bubuk jahe emprit. Bubuk jahe emprit pada penelitian ini memiliki kadar air sebesar 7,04\%. Hal ini sesuai dengan penelitian Eze (2011), bahwa bubuk jahe emprit memiliki kadar air yang tinggi yaitu berkisar $7-12 \%$. Kadar air dapat menentukan kesegaran dan daya awet bahan pangan. Apabila kadar air dalam teh kering cukup banyak maka akan menyebabkan teh menjadi lembab dan mudah rusak (Herawati dan Agus, 2007). Kadar air teh yang ditetapkan oleh SNI maksimal sebesar 8\% (Anon., 2013). Hasil penelitian yang diperoleh bahwa penambahan bubuk jahe emprit hingga 20\% telah sesuai dengan standar mutu teh yang ditetapkan oleh SNI. Namun, penambahan bubuk jahe emprit sebanyak $30 \%$ dan $40 \%$ belum memenuhi standar yang ditetapkan oleh SNI. Hal ini disebabkan karena kadar air bubuk jahe emprit yang tinggi, sehingga menyebabkan peningkatan kadar air teh celup herbal daun ciplukan lebih dari $8 \%$.

\section{Total Fenol}

Hasil sidik ragam menunjukkan bahwa perlakuan penambahan bubuk jahe berpengaruh sangat nyata $(\mathrm{P}<0,01)$ terhadap total fenol teh celup herbal daun ciplukan. Berdasarkan Tabel 1 dapat dilihat bahwa total fenol tertinggi terdapat pada perlakuan P4 (40\% bubuk jahe) sebesar 1,34 mgGAE/g, sedangkan kadar total fenol terendah terdapat pada perlakuan P0 (0\% bubuk jahe) sebesar 1,03 mgGAE/g.

Tabel 1 menunjukkan total fenol semakin meningkat seiring dengan meningkatnya penambahan bubuk jahe emprit. Hal ini disebabkan karena bubuk jahe emprit dalam penelitian ini mengandung senyawa fenol sebesar 0,54 mgGAE/g. Senyawa fenol yang terdapat dalam jahe emprit merupakan bagian dari komponen oleoresin, yang berpengaruh terhadap rasa pedas. Senyawa fenol dapat berfungsi sebagai antioksidan utama seperti gingerol, shogaol, dan minyak atsiri. Hal ini sejalan dengan hasil penelitian Kikuzaki dan Nakatani (1993) yang menjelaskan bahwa senyawa aktif non volatil fenol seperti gingerol dan shogaol yang terdapat pada jahe terbukti memiliki kemampuan sebagai antioksidan. Senyawa-senyawa fenol mampu menghambat reaksi oksidasi melalui mekanisme penangkapan radikal dengan cara menyumbangkan satu elektron pada elektron yang tidak berpasangan dalam 
radikal bebas sehingga banyak radikal bebas menjadi berkurang serta mencegah proses peradangan pada sel tubuh (Waji, 2009).

\section{Total Flavonoid}

Hasil sidik ragam menunjukkan bahwa perlakuan penambahan bubuk jahe berpengaruh sangat nyata $(\mathrm{P}<0,01)$ terhadap total flavonoid teh celup herbal daun ciplukan. Berdasarkan Tabel 1 dapat dilihat bahwa total flavonoid tertinggi terdapat pada perlakuan P4 (40\% bubuk jahe) sebesar 0,63 mgQE/g, sedangkan flavonoid terendah terdapat pada perlakuan P0 ( $0 \%$ bubuk jahe) sebesar $0,49 \mathrm{mgQE} / \mathrm{g}$.

Tabel 1 menunjukkan total flavonoid semakin meningkat seiring dengan meningkatnya penambahan bubuk jahe emprit. Hal ini disebabkan karena bubuk jahe emprit dalam penelitian ini mengandung senyawa flavonoid sebesar $0,14 \mathrm{mgQE} / \mathrm{g}$. Senyawa flavonoid yang terkandung dalam jahe antara lain adalah kuersetin, rutin, katekin, dan epikatekin, yang merupakan flavonoid golongan flavonol yang memiliki sifat semi polar (Ghasemzadeh dkk., 2010). Flavonoid dapat bertindak sebagai antioksidan dengan cara menangkap radikal bebas, sehingga dapat mencegah penyakit - penyakit kronis dan degeneratif seperti kanker dan jantung (Putri, 2012). Flavonoid dapat berperan secara langsung sebagai degeneratif dengan cara mengganggu fungsi dari mikroba seperti bakteri atau virus (Waji, 2009).

\section{Aktivitas Antioksidan dan IC $_{50}$}

Hasil sidik ragam menunjukkan bahwa perlakuan penambahan bubuk jahe berpengaruh sangat nyata $(\mathrm{P}<0,01)$ terhadap aktivitas antioksidan teh celup herbal daun ciplukan. Berdasarkan Tabel 1 dapat dilihat bahwa aktivitas antioksidan tertinggi terdapat pada perlakuan P4 (40\% bubuk jahe) sebesar 70,11\%, sedangkan aktivitas antioksidan terendah terdapat pada perlakuan P0 (0\% bubuk jahe) sebesar $31,23 \%$.

Tabel 1 menunjukkan aktivitas antioksidan semakin meningkat seiring dengan meningkatnya penambahan bubuk jahe emprit. Hal ini disebabkan karena bubuk jahe emprit dalam penelitian ini memiliki aktivitas antioksidan sebesar $21,76 \%$. Aktivitas antioksidan dipengaruhi oleh senyawa fenol dan flavonoid yang terkandung dalam teh celup herbal daun ciplukan. Semakin tinggi kandungan fenol dan flavonoid maka akan semakin tinggi aktivitas antioksidan. Jahe emprit memiliki komponen fenol seperti gingerol dan shogaol yang terdapat dalam oleoresin jahe. Oleoresin jahe bersifat sebagai antioksidan karena dapat mencegah proses oksidasi dengan menutup atau menangkap radikal bebas. Hasil penelitian Hernani dan Winarti (2014), menjelaskan bahwa senyawa antioksidan alami dalam jahe cukup tinggi dan sangat efisien dalam menghambat radikal bebas. 
Berdasarkan hasil analisis aktivitas antioksidan, teh celup herbal daun ciplukan dengan penambahan bubuk jahe emprit memiliki nilai $\mathrm{IC}_{50}$ berkisar antara 1593,68 ppm - 652,95 ppm. Teh celup herbal daun ciplukan dengan penambahan bubuk jahe emprit memiliki potensi antioksidan sangat lemah dimana nilai $\mathrm{IC}_{50}$ menunjukkan lebih dari 200 ppm. Secara spesifik, suatu senyawa dikatakan sebagai antioksidan sangat kuat jika nilai $\mathrm{IC}_{50}$ kurang dari 50 ppm, antioksidan kuat untuk $\mathrm{IC}_{50}$ antara 50 100 ppm, antioksidan sedang jika nilai $\mathrm{IC}_{50}$ bernilai 101 - 150 ppm, antioksidan lemah jika IC $_{50}$ bernilai 151 - 200 ppm dan antioksidan sangat lemah jika $\mathrm{IC}_{50}$ bernilai lebih dari 200 ppm (Rahmawati, 2004).

\section{Karakteristik Sensori}

Karakteristik sensori teh celup herbal daun ciplukan dilakukan dengan uji rangking dan hedonik. Uji rangking dilakukan terhadap warna, aroma, dan rasa sedangkan uji hedonik dilakukan terhadap aroma dan penerimaan keseluruhan. Nilai rata - rata uji rangking terhadap warna, aroma, dan rasa dapat dilihat pada Tabel 2, sedangkan nilai rata - rata uji hedonik terhadap aroma dan penerimaan keseluruhan dapat dilihat pada Tabel 3.

Tabel 2. Nilai rata - rata uji rangking terhadap warna, aroma, dan rasa teh celup herbal daun ciplukan

\begin{tabular}{cccc}
\hline $\begin{array}{c}\text { Perlakuan penambahan bubuk jahe } \\
(\%)\end{array}$ & $\begin{array}{c}\text { Warna } \\
*\end{array}$ & $\begin{array}{c}\text { Aroma } \\
* *\end{array}$ & $\begin{array}{c}\text { Rasa } \\
* * *\end{array}$ \\
\hline P0 (0\%) & $1 \pm 0,40^{\mathrm{a}}$ & $1 \pm 0,28^{\mathrm{a}}$ & $5 \pm 0,84^{\mathrm{e}}$ \\
P1 $(10 \%)$ & $2 \pm 0,40^{\mathrm{b}}$ & $2 \pm 0,72^{\mathrm{b}}$ & $4 \pm 0,89^{\mathrm{d}}$ \\
P2 $(20 \%)$ & $2 \pm 0,37^{\mathrm{c}}$ & $3 \pm 0,62^{\mathrm{c}}$ & $3 \pm 0,40^{\mathrm{c}}$ \\
P3 $(30 \%)$ & $4 \pm 0,50^{\mathrm{d}}$ & $4 \pm 0,71^{\mathrm{d}}$ & $2 \pm 0,88^{\mathrm{b}}$ \\
P4 (40\%) & $5 \pm 0,50^{\mathrm{d}}$ & $5 \pm 0,87^{\mathrm{e}}$ & $1 \pm 0,92^{\mathrm{a}}$ \\
\hline
\end{tabular}

Keterangan: Nilai rata-rata yang diikuti oleh huruf yang berbeda pada kolom yang sama menunjukkan perlakuan yang berbeda sangat nyata $(\mathrm{P}<0,01)$.

* 1 = coklat kemerahan, $2=$ coklat kehijauan, $3=$ coklat kekuningan, $4=$ hijau kekuningan, $5=$ kuning.

** 1 = sangat khas teh daun ciplukan, $2=$ khas teh daun ciplukan, $3=$ agak khas teh daun ciplukan, $4=$ tidak khas teh daun ciplukan, 5 = sangat tidak khas teh daun ciplukan.

*** 1 = sangat tidak pahit, $2=$ tidak pahit, $3=$ agak pahit, $4=$ pahit, $5=$ sangat pahit.

\section{Warna}

Hasil uji rangking menunjukkan bahwa perlakuan penambahan bubuk jahe berpengaruh sangat nyata $(\mathrm{P}<0,01)$ terhadap warna seduhan teh celup herbal daun ciplukan. Nilai rata-rata urutan pertama diperoleh pada perlakuan P0 (0\% bubuk jahe) dengan kriteria coklat kemerahan sedangkan urutan kelima diperoleh pada perlakuan P4 (40\% bubuk jahe) dengan kriteria kuning dan berbeda tidak nyata dengan perlakuan P3 (30\% bubuk jahe).

Tabel 2 menunjukkan warna seduhan teh celup herbal daun ciplukan semakin kuning seiring dengan meningkatnya penambahan bubuk jahe emprit. Warna air 
seduhan teh celup herbal daun ciplukan tanpa penambahan bubuk jahe emprit memiliki warna yang lebih gelap dibandingkan warna air seduhan dengan penambahan bubuk jahe. Hal ini disebabkan karena seduhan jahe emprit memiliki kandungan oleoresin yang menghasilkan warna kekuningan akan menetralkan warna seduhan daun ciplukan berupa coklat kemerahan sehingga semakin besar penambahan bubuk jahe kedalam teh celup herbal daun ciplukan maka warna air seduhan akan semakin terang. Hal ini sesuai dengan penelitian Muzaki dan Wahyuni (2015) yang menyatakan bahwa semakin banyak penambahan jahe emprit maka semakin tinggi nilai kecerahannya.

Tabel 3. Nilai rata - rata uji hedonik aroma dan penerimaan keseluruhan

\begin{tabular}{ccc}
\hline $\begin{array}{c}\text { Perlakuan penambahan bubuk jahe } \\
(\%)\end{array}$ & $\begin{array}{c}\text { Aroma } \\
* * * *\end{array}$ & $\begin{array}{c}\text { Penerimaan Keseluruhan } \\
* * * *\end{array}$ \\
\hline P0 $(0 \%)$ & $1,96 \pm 0,53^{\mathrm{d}}$ & $2,56 \pm 1,29^{\mathrm{c}}$ \\
P1 (10\%) & $2,32 \pm 0,47^{\mathrm{d}}$ & $3,04 \pm 1,21^{\mathrm{bc}}$ \\
P2 (20\%) & $3,20 \pm 0,76^{\mathrm{c}}$ & $3,44 \pm 1,19^{\mathrm{b}}$ \\
P3 (30\%) & $4,20 \pm 0,91^{\mathrm{b}}$ & $4,36 \pm 1,35^{\mathrm{a}}$ \\
P4 (40\%) & $5,48 \pm 0,51^{\mathrm{a}}$ & $4,68 \pm 1,41^{\mathrm{a}}$ \\
\hline
\end{tabular}

Keterangan: Nilai rata-rata yang diikuti oleh huruf yang berbeda pada kolom yang sama menunjukkan perlakuan yang berbeda sangat nyata $(\mathrm{P}<0,01)$.

$* * * * 1=$ sangat tidak suka, $2=$ tidak suka, $3=$ agak tidak suka, $4=$ biasa, $5=$ agak suka, $6=$ suka, $7=$ sangat suka

\section{Aroma}

Hasil uji rangking menunjukkan bahwa perlakuan penambahan bubuk jahe berpengaruh sangat nyata $(\mathrm{P}<0,01)$ terhadap aroma seduhan teh celup herbal daun ciplukan. Nilai rata-rata urutan pertama diperoleh pada perlakuan P0 (0\% bubuk jahe) dengan kriteria sangat khas teh daun ciplukan sedangkan urutan kelima diperoleh pada perlakuan P4 (40\% bubuk jahe) dengan kriteria sangat tidak khas teh daun ciplukan dan berbeda tidak nyata dengan perlakuan P3 (30\% bubuk jahe).

Teh celup herbal daun ciplukan dengan perlakuan $\mathrm{P} 0$ (0\% penambahan jahe) memiliki nilai urutan pertama karena aroma off-flavour khas teh herbal daun ciplukan yang dapat dirasakan ketika proses penyeduhan. Teh celup herbal daun ciplukan dengan perlakuan $\mathrm{P} 4$ (40\% penambahan jahe) memiliki nilai urutan kelima karena dengan adanya penambahan bubuk jahe dapat mengurangi aroma off-flavour khas seduhan teh celup herbal daun ciplukan. Jahe emprit menghasilkan bau harum yang disebabkan oleh adanya minyak volatil yang terdiri dari zingiberene dan zingiberol sehingga dengan semakin meningkatnya penambahan bubuk jahe maka aroma offflavour khas teh herbal daun ciplukan akan semakin berkurang. 
Hasil sidik ragam menunjukkan bahwa perlakuan penambahan bubuk jahe berpengaruh sangat nyata $(\mathrm{P}<0,01)$ terhadap aroma seduhan teh celup herbal daun ciplukan. Nilai rata-rata kesukaan panelis terhadap aroma teh celup tertinggi diperoleh pada perlakuan P4 (40\% bubuk jahe) yaitu 5,48 dengan kriteria agak suka sedangkan nilai terendah diperoleh pada perlakuan P0 (0\% bubuk jahe) yaitu 1,96 dengan kriteria tidak suka dan berbeda tidak nyata dengan perlakuan P1 (10\% bubuk jahe).

Tabel 3 menunjukkan aroma seduhan teh celup herbal daun ciplukan semakin disukai oleh panelis seiring dengan meningkatnya penambahan bubuk jahe emprit. Air seduhan teh herbal daun ciplukan tanpa penambahan bubuk jahe emprit memiliki aroma kesukaan terendah karena daun ciplukan memiliki aroma off-flavour yang dinilai oleh panelis tidak enak. Hal ini sesuai dengan pendapat Lee dkk., 2013 yang menyatakan bahwa aroma yang tidak enak pada daun berupa aroma yang berasal dari kelompok senyawa aldehid alifatik yaitu dari senyawa volatile 3-Methyl-butanal. Air seduhan teh herbal daun ciplukan dengan penambahan bubuk jahe emprit hingga $40 \%$ memiliki aroma kesukaan tertinggi. Hal ini disebabkan oleh adanya minyak volatil pada bubuk jahe emprit yang terdiri dari zingiberen dan zingiberol sehingga menghasilkan aroma jahe yang khas. Semakin banyak penambahan bubuk jahe emprit maka semakin tinggi nilai kesukaan panelis terhadap aroma teh herbal daun ciplukan.

\section{Rasa}

Hasil uji rangking menunjukkan bahwa perlakuan penambahan bubuk jahe berpengaruh sangat nyata $(\mathrm{P}<0,01)$ terhadap rasa seduhan teh celup herbal daun ciplukan. Nilai rata-rata urutan pertama diperoleh pada perlakuan P4 (40\% bubuk jahe) dengan kriteria sangat tidak pahit dan berbeda tidak nyata dengan perlakuan P3 (30\% bubuk jahe), sedangkan urutan kelima diperoleh pada perlakuan P0 ( $0 \%$ bubuk jahe) dengan kriteria sangat pahit.

Teh celup herbal daun ciplukan dengan perlakuan P4 (40\% penambahan jahe) memiliki nilai urutan pertama karena semakin banyak penambahan bubuk jahe emprit maka rasa pahit teh celup semakin berkurang. Rasa jahe memberikan rasa khas pada teh celup karena memiliki kandungan oleoresin. Oleoresin memiliki komponen pemberi rasa pedas yang disebabkan oleh adanya kandungan ginggerol dan shogaol. Jahe emprit memiliki keunggulan yaitu memiliki kandungan gingerol dan shogaol tertinggi diantara ketiga jenis jahe, yaitu $22,57 \mathrm{mg} / \mathrm{g} ; 2,24 \mathrm{mg} / \mathrm{g}$, jahe merah 18,03 $\mathrm{mg} / \mathrm{g} ; 1,36 \mathrm{mg} / \mathrm{g}$, dan jahe gajah 9,56 mg/g ; 0,92 mg/g (Fathona, 2011). Rasa seduhan teh herbal daun ciplukan dengan perlakuan P0 (0\% penambahan jahe) memiliki nilai urutan kelima. Hal ini dikarenakan rasa pahit seduhan daun ciplukan berasal dari senyawa saponin dan alkaloid yang sekaligus 
memberikan manfaat berupa antitumor dan menghambat pertumbuhan kanker usus besar (Taryati, 2010). Selain itu adanya kandungan flavonoid dan tanin dalam tanaman ciplukan juga berkontribusi dalam memberikan rasa pahit.

\section{Penerimaan Keseluruhan}

Hasil sidik ragam menunjukkan bahwa perlakuan penambahan bubuk jahe berpengaruh sangat nyata $(\mathrm{P}<0,01)$ terhadap penerimaan keseluruhan seduhan teh celup herbal daun ciplukan. Berdasarkan Tabel 3 menunjukkan nilai rata-rata uji hedonik terhadap penerimaan keseluruhan teh celup berkisar antara 2,56 (agak tidak suka) sampai dengan 4,68 (agak suka). Penerimaan keseluruhan teh celup dipengaruhi oleh berbagai faktor seperti warna, aroma, dan rasa.

\section{KESIMPULAN DAN SARAN}

\section{Kesimpulan}

Penambahan bubuk jahe emprit pada teh celup herbal daun ciplukan berpengaruh sangat nyata $(\mathrm{P}<0,01)$ terhadap kadar air, total fenol, total flavonoid, aktivitas antioksidan, $\mathrm{IC}_{50}$, warna, aroma, rasa, dan penerimaan keseluruhan. Penambahan 20\% bubuk jahe emprit menghasilkan teh celup herbal daun ciplukan dengan karakteristik terbaik. Karakteristik teh celup herbal daun ciplukan yang dihasilkan yaitu kadar air $7,84 \%$, total fenol $1,18 \mathrm{mgGAE} / \mathrm{g}$, total flavonoid $\quad 0,56 \quad \mathrm{mgQE} / \mathrm{g}, \quad$ aktivitas antioksidan 58,02\%, $\mathrm{IC}_{50} 812,96 \mathrm{ppm}$.
Adapun karakteristik air seduhan teh yang dihasilkan yaitu warna coklat kekuningan, aroma agak khas teh daun ciplukan dan agak tidak suka, rasa agak pahit, dan penerimaan keseluruhan agak tidak suka.

\section{Saran}

1. Untuk membuat teh celup herbal daun ciplukan, disarankan menggunakan penambahan $20 \%$ bubuk jahe emprit.

2. Perlu dilakukan uji hedonik terhadap warna dan rasa untuk mengetahui tingkat kesukaan panelis.

\section{DAFTAR PUSTAKA}

Anonimus. 2013. SNI 2836:2013. Teh kering dalam kemasan. Badan Standar Nasional, Jakarta.

Daroini, O.S. 2016. Kajian proses pembuatan teh herbal dari campuran teh hijau (Camellia sinensis), rimpang bangle (Zingiber assumunar roxb.) dan daun ceramai (Phyllanthus acidus (L). Skeels). Skripsi. Tidak dipublikasikan. Fakultas Teknologi Pertanian IPB, Bogor.

Eze, J.1. dan K.E. Agbo. 2011. Comparative studies of sun and solar drying of peeled and unpeeled ginger. American Journal of Scientific and Industrial Research. 2(2): 136-143.

Fitria, M., Armandari, I. Septeha. D.B. Ikawati. A.H.M dan E. Meiyanto. Ekstrak etanolik herba ciplukan (Physalis angulata L.) berefek sitotosik dan menginduksi apoptosis pada sel kanker payudara MCF-7. Fakultas Farmasi. 13: 101-107.

Fathona, D. 2011. Kandungan gingerol dan shogaol, intensitas kepedasan dan penerimaan panelis terhadap oleoresin jahe gajah (Zingiber Officinale Var. Roscoe), jahe emprit (Zingiber officinale var. Amarum), dan jahe merah (Zingiber Officinale Var. Rubrum). Skripsi. Tidak dipublikasi. Fakultas Teknologi Pertanian IPB, Bogor. 
Ghasemzadeh, A., H.Z. Jafar and A. Rahmat. 2010. Synthesis of phenolic and flavonoids in ginger (Zingiber officinale Roscoe) and their effect on photosynthesis rate. Molecular Science. 11:4539-4555.

Hanani, E. A. Mun'im dan E. Sekarini. 2005. Identifikasi senyawa antioksidan dalam spons Callyspongia sp. dari kepulauan seribu. Majalah Ilmu Kefarmasian. 2(3): 127-133.

Herawati, H. dan N. Agus. 2007. Peningkatan nilai tambah produk teh hijau rakyat di Kecamatan Cikalong Wetan-Kabupaten Bandung. Jurnal Pengkajian dan Pengembangan. Teknologi Pertanian. 10(3):241-249.

Hernani dan C. Winarti. 2014. Kandungan bahan aktif jahe dan pemanfaatannya dalam bidang kesehatan. Balai Besar Penelitian dan Pengembangan Pascapanen Pertanian, Bogor.

Irmayanti. 2017. Bahan ajar evaluasi sensori. Fakultas Teknologi Pertanian USM, Banda Aceh.

Kikuzaki, H. and N. Nakatami.1993. Antioxidant effects of some ginger constituents. J. Bul. Food science. 58(6):1407-1410.

Lee, J., D.H. Chambers, E. Chambers, K. Adhikari dan Y. Yoon. 2003. Volatile aroma compounds in various brewed green teas. Molecules. 18:10024-10041.

Muzaki, D. dan W. Reksa. 2015. Pengaruh penambahan gingger kering (Zingiber officinale) terhadap mutu dan daya terima teh herbal daun afrika selatan (Vernonia amygdalina). Teknologi Pangan. 6(2):6775.

Nuranda, A., S. Chairul dan Y. Bohari. 2016. Potensi tumbuhan ciplukan (Physalis angulata linn) sebagai antioksidan alami. Fakultas Matematika dan Ilmu Pengetahuan Alam. 01(1):5-9.

Rahmawati, D. 2004. Mempelajari aktivitas antioksidan dan mikroba ekstrak antarasa (Litsea cubeba) dan aplikasinya sebagai pengawet alami pada bahan pangan. Skripsi. Fakultas Teknologi Pertanian IPB, Bogor.

Rosidi, A., A. Khomsan, B. Setiawan, H. Riyadi dan D. Briawan. 2014. Potensi temulawak (Curcuma xanthorrhiza Roxb) sebagai antioksidan. Fakultas Ilmu
Keperawatan dan Kesehatan UNIMUS, Semarang.

Rahman, A., Riyanto dan Utari. 2006. Aktivitas antioksidan, kandungan fenolat total dan kandungan flavonoid total ekstrak etil asetat buah mengkudu serta fraksi-fraksinya. Majalah Farmasi Indonesia. 17:137-13.

Suprianto. 2013. Efektifitas teh ciplukan (Physaws minima L) terhadap diabetes melitus. Bul. Stikes Hervetia. 6(12):9-13.

Steel, R.G.D dan J.H. Torrie. 1993. Prinsip dan prosedur statistika suatu pendekatan biometrik. Penerjemah B. Sumantri. PT. Gramedia Pustaka, Jakarta.

Sudarmadji, S., B. Haryono dan Suhardi. 1997. Prosedur analisa untuk bahan makanan dan pertanian. Liberty, Yogyakarta.

Sakanaka, S., Y. Tachibana, Okada dan Yuki. 2005. Preparation and antioxiant properties of extracts of Japanese persimo leaf tea (Kakinocha-cha) food chemistry. 89.569-575.

Sulistiani, P.N., Tamrin, A.R Baco. 2019. Kajian pembuatan minuman fungsional dari daun sirsak (Annona Muricata Linn.) Dengan penambahan bubuk jahe (Zingiber Officinale). Food Technol. 4(2):2086-2095.

Susanti, T.M.I dan B. Panunggal. 2015. Analisis antioksidan, total fenol dan kadar kolesterol pada kuning telur asin denngan penambahan ekstrak jahe. Ilmu Gizi. 4(2):636-644.

Phuah, E., A. Khalafallah, A. Al-barazan, I. Nikakis, A. Radford, W. Clarkson and A. Corbould. 2016. Glycosylated haemoglobin for screening and diagnosis of gestational diabetes mellitus. 011059. https://doi.org/10.1136/bmjopen-2016011059. Diakses 26 November 2019.

Pebiningrum, A. dan J. Kusnadi. 2018. Pengaruh varietas jahe (Zingiber officinale) dan penambahan madu terhadap aktivitas antioksidan minuman fermentasi kombucha jahe. Food Technol. 1(2):33-42.

Taryati. 2010. Evaluasi penambahan ekstrak ciplukan (Physalis angulata) dalam air minum terhadap daya hambat bakteri Salmonella typhimurium dan performa puyuh (Coturnix coturnix japonica) 0-4 minggu. Skripsi. Tidak dipublikasi. Fakultas Peternakan IPB. Bogor. 
Waji, R.A. 2009. Flavonoid (Quercetin). Makalah Kimia Organik Bahan Alam. Fakultas Matematika dan Ilmu
Pengetahuan Alam. Universitas Hasanuddin. Makassar. 